\title{
Basic Social Values Reflection: Concept 'Honor' in English, German and Russian Linguocultures
}

\author{
Tatyana Shevchenko ${ }^{1, *}$, Genadii Slyshkin ${ }^{2}$, Anna Moseyko ${ }^{1}$ and Kristina Korovina ${ }^{1}$ \\ ${ }^{1}$ Volgograd State Social Pedagogical University, Theory of English Department, 400066 Lenin Av. 27, Volgograd, Russia \\ ${ }^{2}$ Russian University of Transport (MIIT), Department of Social Sciences and Professional Communication, 127994 GSP-4, \\ Obraztsov St. 9-9 Moscow, Russia
}

\begin{abstract}
The subject of this paper is to present the results of the study detailing the essence of the value concept 'honor' within the framework of English, German and Russian language cultures as a reflection of the basic values of society in the today's linguistic world. The methods of the research were theoretical analysis of the works of philologists and pedagogues on the structure and essence of the value concept 'honor' as a synergetic unity of the two notions. The component analysis of dictionary definitions and their subsequent step-by-step identification is given. A review of various treatments of 'honor' is suggested, ranging from 'respect', 'reputation', 'faith', 'mark of approval', 'creditable' to 'dishonor', 'discredit', 'shame', 'ill repute' and so on. An attempt is made to characterize 'honor' as one of the axiological concepts and a socially and culturally conditional pattern of approval/disapproval.
\end{abstract}

\section{Introduction}

The most important cultural characteristics of any national, social or professional group are reflected primarily in the specific language features of the group. These are the language elements that contain various socio-psychological attitudes, stereotypes of consciousness and automatism of thinking, i.e. all, that in modern science is called mentality. "The language of the nation is in itself a concise, if you will, algebraic expression of the entire culture of the nation" $[1,9]$. It is not accidental, therefore, that in the current situation of increased interest in cultural and regional studies, there is an intensive interpenetration and mutual enrichment of linguistics and a number of other Humanities that touch upon cultural issues [2-6]. There is a profound connection between the history of the people and the development of their language, which means that there are similarities and differences in cultures of different peoples, each of which has passed its own unique historical path, can be identified on the basis of similarities and differences in their national languages. "... 'continuum' of the research field in the sphere of the history of culture is created by the fact that three research areas - 'history of spiritual values (concepts of culture)', 'history of words', 'history of things' - are connected $[7,11]$.

\section{Methodology}

The key to the study of the peculiarity of ethno-cultural dominant in the natural language is the notion of cultural and linguistic concept. In modern linguistics, there are four main approaches to understanding the term ' concept':

1) as a synonym for the term 'notion'. In this sense, the 'concept' is perceived by proponents of logical modeling of semantics, defining it as a thought containing a generalized form of objects and phenomena of reality by fixing their properties and relations [8, 35].

2) D.S. Likhachev puts forward a psychological definition of the concept. He considers the concept to be a substitute for the notion in the individual and collective consciousness of native speakers, "a kind of 'algebraic' expression of the meaning that we operate in our oral and written speech, because a person simply can not cover the meaning in all its complexity; sometimes a person can not, and sometimes interprets it in his own way (depending on his education, personal experience, belonging to a certain environment, profession, etc.)" [9, 4].

3) H.D. Arutyunova interprets concept as the notion of practical (everyday) philosophy, which is the result of the interaction of a number of factors, such as national tradition, folklore, religion, ideology, life experience, images of art, feelings and a system of values. Concepts form "a kind of cultural layer coming in between man and the world" [10,3].

4) Integrative understanding of the concept was

Corresponding author: shefdtj@yandex.ru 
proposed иу S.H. Lyapin, who defines the concept as "multidimensional culturally significant sociopsychological notion in the collective consciousness, objectified in this or that language form" $[11,6]$. In this sense, the concept will be understood in this paper.

It should be noted that there might be some asymmetry between the conceptual and semantic spheres of the language, i.e. the absence of rigid mutually unambiguous relations. Each cultural and linguistic concept and each of its aspects will not necessarily correspond to a specific lexical unit. Such situation is in principle impossible. However, "even if the ideosemantic system of this language has not provided a special analogue to a concept, this concept can be expressed in a descriptive way by a syntagmatic configuration of word signs" $[12,102]$.

\section{Results and discussion}

The whole range of the main concepts of the language forms a certain amount of views, denoted by modern linguistics as a 'naive picture of the world', an indispensable carrier of which is every native speaker of the language. The naive picture of the world is a kind of collective philosophy, a way of the ordered perception by the person of himself and surrounding reality. It has been developing for centuries and reflects the spiritual experience of the people - native speakers, for whom it is specific in two respects. Firstly, the naive picture of the world can be very different from the scientific picture of the world, common for all people, regardless of the language, which they speak. Secondly, naive pictures of the world of different peoples have purely national features, i.e. speakers of different languages see the world a little differently through the prism of their languages. The naive picture of the world is no less complex and systemic than the scientific picture of the world. In the naive picture of the world we can single out naive geometry, naive physics, naive psychology, naive ethics, etc. [13, 56-59; 14, 349-351].

Since the subject of our study is the value concept of 'honor', we will be interested primarily in the field of naive ethics, which is often very different from the official ethics, and in some moments it may be directly opposite. For example, only interpersonal relationships are important for a carrier of Argentine culture. The state is an abstract entity; it cannot be clearly represented and personalized in the language (as, for example, 'Uncle Sam' for Americans). Therefore, despite the seriousness of the punishment prescribed by law, at the everyday level, embezzlement from the state treasury by Argentines is not perceived as a crime and does not contradict the concept of 'honor' $[15,52]$.

Most areas of the naive picture of the world (naive physics, etc.) are opposed to the scientific picture of the world, i.e. to the attempts to comprehend reality objectively. Ethics also includes a system of norms of human behavior in a society and, being based on the whole range of public attitudes, customs and traditions, has no direct connection with the objective reality existing outside and beyond the human will. Naive ethics should be opposed to the ethics official, which is based on ideological values implanted in the consciousness of the individual by authorities. Naive ethics, functioning by means of the influence on it of the values concluded in language units unknown by the native speaker, and official ethics, influencing the person through institutional discourse, are in a situation of continuous mutual influence occurring according to very difficult laws. It is reasonable to consider naive ethics as part of a special aspect of the naive picture of the world - the valuable picture of the world in language.

V.I. Karasik highlights the following characteristics of the valuable picture of the world in the language:

1) the combination of a universal element and a specific element, reducing to a different nominative density of objects, their different assessment skills, different combinatorics of value concepts;

2) its reconstructibility in the form of interrelated evaluation judgments correlated with the main significant text examples of this culture (various codes and products of folk or author's creativity);

3) presence of the relations of inclusion and associative intersection between these value judgments, which gives the opportunity to set the value paradigms of the culture;

4) existence in the value picture of the world of value dominants, the whole range of which forms a certain type of culture;

5) heterogeneity of the value picture of the world among different social groups within the framework of one language culture;

6) existence of valuable pictures of the world both in collective and in individual consciousness $[16,5]$.

The evaluation value and nature of values has long been of great interest to representatives of various Sciences, including linguistics. The concept of 'honor' occupies a special place in the evaluation mechanism described above. On the one hand, being one of the axiological concepts, it belongs to the world of values, but on the other hand, being a socially and culturally conditioned pattern of approval/disapproval, it serves as one of the motives for the evaluation of various objects, thus, entering the mode of belief.

In this paper, the value concept 'honor' will be considered within the framework of English, German and Russian language cultures, firstly, on the material of vocabulary and phraseology, as language levels most clearly demonstrating the 'naïve' perception of values by native speakers, secondly, on the material of precedential texts of these cultures, i.e. in the sphere of active mutual influence of naive and official ethical systems, and, thirdly, in the context of the use of this concept by native speakers in communicative strategies.

The concept 'honor' is a syncretic unity of the two concepts. Honor is, first of all, a pattern of social approval/disapproval, and secondly, a set of manifestations of this approval/disapproval (often marked).

Using the method of the component analysis of dictionary definitions and their subsequent step-by-step 
identification, we have identified the following lexical units of English connected with the concept 'honor':

- honor, homage, deference, reverence, esteem, respect, admiration, worship, adoration, glory, fame, veneration, trust, faith, confidence, recognition, praise, attention, notice, consideration, renown, reputation, repute, good name, account, laurels, elevation, approbation, wreath, credit, eulogium, adulation, laud, tribute, celebration, popularity, exaltation, apotheosis, lionization, immortalisation, fealty, good report, high reward, glorification, mark of approval, deification, dignification, canonization, aggrandizement, righteousness, distinction, title, chastity, purity, virtue;

- dishonor, opprobrium, disgrace, discredit, disesteem, disrepute, infamy, ignominy, obloquy, shame, bad name, bad odour, ill repute;

- to honor, to acclaim, to celebrate, to exalt, to extol, to glorify, to hail, to laud, to magnify, to panegyrize, to praise, to venerate, to admire, to esteem, to consider, to regard, to respect, to value, to distinguish, to elevate, to ennoble, to exalt, to signalize, to grace, to dignify, to favor, to canonize;

- to discredit, to dishonor, to disgrace, to shame

- honorable, reputable, creditable, distinguished, famous, proud, important;

discreditable, dishonorable, disreputable, ignominious, obloquious, opprobrious, shabby, shameful.

The following units are presented in German dictionaries expressing different aspects of the concept 'honor':

- die Ehre, die Selbstachtung, das Ehrgefehl, das Wertgefühl, der Stolz, die Wurde, der Anstand, das Ansehen, die Autorität, das Prestige, die Geltung, die Respektabilität, die Achtung, der Ruf, der Leumund, die Reputation, das Renommee, der Ruhm, die Achtbarkeit, die Ehrenhaftigkeit, die Anständigkeit, die Ehrbarkeit, die Ehrsamkeit, die Ehrpusseligkeit, das Ehrenamt, die Ehrenbezeigung, der Ehrendienst, die Ehrenerklärung;

- die Shande, die Entehrung, die Schmach, die Bloßstellung, die Blamage, der Skandal, der Schimpf, die Unehre, die Affenschande;

- ehren, feiern, preisen, hochhalten, beehren, anerkennen, achten;

- entehren, entwürdigend, schinden, beflecken, beschmutzen, verunehren, herabwürdigen, verleumden, vergewaltigen, verunglimpfen, schlechtmachen, diffamieren, diskreditieren, verlästern, verketzern, anschwärzen, verschreien, herabsetzen, diskriminieren, verkleinern, herabziehen, verkleinern, beeinträchtigen, entwerten, beleidigen;

- achtbar, ehrenwert, honett, ehrenhaft, anständig, wohlachtbar, hochachtbar, ehrbar, ehrsam, ehrenfest, reputierlich, ehrpusselig;

- entehrend, entwürdigend, schändlich, schmachvoll, verächtlich, verletzend.

Russian dictionaries contain the following lexical material related to the concept 'honor':

- honor, reputation, (good) name, fame, honor, respect, veneration, reverence, deference, respect, reverence, honesty, decency, integrity, dignity, purity, innocence, chastity, unspoiled, virginity;
- dishonor, shame, disgrace;

- respect, honor;

- profane, to proclaim, to disgrace, defame, discredit, denigrate, to soil, to disgrace, to defame.

After considering the dictionary material and component analysis of the above units, we have made the following observations:

Lexical units related to the concept 'honor' necessarily contain one of the following three semantic features:

1) identification of the relationship to anyone or anything (i.e. the expression of a particular opinion about someone or something);

2) identification of the external expression of the relation to someone or something;

3 ) the quality of or set of qualities of someone or something, causing this or that attitude to it.

For example, the verb 'to respect', which the Merriam-Webster Dictionary defines as "to consider deserving of high regard" contains the first characteristic, as well as the verb 'to value', 'to admire', 'hochhalten', 'achten', nouns 'esteem', 'respect', 'die Achtung', etc. The second characteristic is contained in the meaning of the verb 'to praise' - to speak with approval of, to speak highly of [17], the verbs 'to magnify', 'panegyrize', 'diffamieren', 'diskreditieren', nouns 'glorification', 'canonization', 'die Ehrenbezeigung' and others. An example of a lexical unit containing the third characteristics is the noun 'die Schande' - etwas worbber man sich schдmehn muя [18], as well as nouns such as 'virtue', 'honesty', etc.

A number of words contain more than one of the three above-mentioned characteristics. For example, the verb 'to worship' - to feel or show great respect [19] combines the first and the second characteristics. The adjective 'honourable' - possessing or showing principles of honor, worthy of honor [20] is characterized by a combination of the second and third characteristics, with the third obviously dominating.

An essential component of all three abovementioned features, typical of lexical units associated with the cultural and linguistic concept 'honor' is the presence of the component of the relationship, i.e. the presence of a certain opinion about someone or something. This opinion can be either positive (for example, 'to esteem - to set high a value on [21]) or negative (for example, 'to discredit' - to reject as untrue [22]). In other words, lexical units expressing the concept 'honor' in English and German necessarily contain an evaluation component which agrees with the definition of 'honor' as a pattern of social approval/disapproval.

The expression of the relationship presupposes the existence of subject and object. The meaning of a number of lexical units implies that the subject of the relationship is the society as a whole or any of its constituent strata. An example of this kind can be nouns 'reporting', 'population', 'immortalisation', 'das Prestige' and many others. In all these cases, the role of the subject of the relationship cannot be a separate individual, i.e. the relationship is not interpersonal but social [23]. Sometimes a lexical unit has a specific 
reference to the subject of the relationship. For example, 'lionization' meaning popularity, or 'die Ehrenbezeigung' meaning paying military honors.

Among the German lexemes associated with explanatory and synonymous dictionaries with the concept 'honor' there is a number of units, the meaning of which involves the combination of the object and the subject of the relationship in one person. For example, 'die Selbstachtung' - self-esteem, 'das Ehrgefhl' pride. It is peculiar that the words of the English language corresponding to them by meaning (selfrespect, self-esteem, and pride) are not given by explanatory and synonymous dictionaries of the English language in connection with the concept of 'honor'. In the synonym series with the dominant 'honor', given in the dictionaries of the Russian language, lexical units with the meaning 'self-respect' do not occur. However, when we interpret the word 'honor' some of the Russian explanatory dictionaries note that honor maintains respect for a person or on the part of others. This gives us grounds to put forward the assumption that in the German language and, to a lesser extent, in the Russian language and the naive pictures of the world, which they make up, the concept 'honor' has both the dominant element of sociality and the element of personal, psychological, expressing not only the public attitude but the attitude of the individual to himself. In English dictionaries there is no such noticeable indication of such an element of the concept 'honor'.

Let us consider the lexical units of the English, German and Russian languages, which are the most associated with the concept 'honor', i.e. the Russian word for 'honor' and its English and German equivalents. The most used of them are English 'honor' and German 'die Ehre'. Let us compare the range of meanings covered by them, having summarized the data of all dictionaries we have used.

The word 'honor' has the following meanings (dictionary meanings are given in descending order of importance of the place given to them in dictionaries):

1. High / great / special / deferential respect / regard / esteem.

2. Wide and good reputation/name/fame.

3. Act or fact of being true to what is right; fine of what is just; fidelity to principles; integrity.

4. Special mark / sign / recognition of respect / esteem / merit / distinction / distinguished services.

5. A title of respect for a high official such as a judge or a mayor.

6. A person or a thing that rings respect.

7. High rank, achievement, distinction.

8. Chastity and purity of a woman.

9. In cards: the five highest cards in the trump suit, or the four aces in no trump.

10. Special recognition for individual achievement in one's study.

11. Golf: a right of playing first.

The word 'Ehre' includes the following meanings:

1. Respect from people around, caused by high merits (Ansehen / Achtung / Anerkennung auf Grund offenbaren Wertes, Wertschätzung durch andere Menschen).
2. Respect, distinction (Zeichen / Bezeigung der Wertschätzung, Ehrenerweis).

3. Self-esteem (Gefühl für die eigene Ehre, Selbstachtung, innere Würde).

4. Purity, innocence of a woman (Jungfräulichkeit).

5. The term of the game of Golf: the right of the first stroke (Golf: Berechtigung, den ersten Schlag auf einem Abschlag zu machen).

Having analyzed five Soviet dictionaries of the Russian language, we have not found any meaning of the word 'honor', found in all of them without exception. Two interpretations can be distinguished as the most general and significant, as each of them appeared in four dictionaries out of the five:

1. The whole range of the highest moral and ethical principles of the individual, moral or social dignity, something that causes and maintains respect [for yourself or on the part of others].

2. Honor, respect.

The following meanings were less common:

3. Chastity, purity, virginity of women (in two of the three dictionaries it used as the shade of the first meaning).

4. High rank, position, honour (marked 'obsolete').

5. About something, someone that is being proud of; someone or something they pay tribute to.

We see that the British 'honor' has much more meanings than the Russian and German word. The correlation of the considered meanings (eleven to five) can hardly be explained only by the polysemantic characteristic of the English language.

In all three cases the meanings, expressing social assessment and the ways of its manifestation, prevail. However, the third meaning of the word 'Ehre' and sometimes the shade of the first meaning of the Russian word 'honor', which is not equivalent to the English word 'honor', testifies in favor of our hypothesis about the presence of the concept 'honor' in the German and Russian linguistic pictures of the world of personal, selfassessment element that does not correspond to the naive picture of the world expressed in English. The absence of a common approach to the interpretation of the word 'honor' in Russian-language dictionaries can serve as evidence of a weak degree of certainty of the concept 'honor' in the Russian naive picture of the world (although perhaps this fact is explained only by the shortcomings of Russian lexicography).

'Honor', in addition to the general social sense, has a number of very specific terminological meanings associated with various spheres of human activity: gambling (cards), education, sports (golf) [24]. 'Ehre' can also be used as a term from golf, but given that golf appeared in England and was only borrowed by the Germans, we can confidently say that we are dealing with a literal translation of the English term into German (cf. Russian 'angled' from the English 'corner'). Russian 'honor' is not associated with such spheres.

A separate group of lexical units related to the concept 'honor' make up the words chastity, purity, honor, Jungfräulichkeit), die Unberührtheit, die Unschuld, die Jungfernschaft, die Virginität, die Ehre, purity, innocence, unspoiled, virginity, signifying the 
honor of women. They contain a third of the mentioned semantic features - the quality or set of qualities of someone or something that causes him any attitude. The linguistic picture of the world keeps traces of those stages of historical development when military, trade and other prestigious spheres of activity were men's prerogative. The destiny of women was the family, and therefore, the main socially evaluated female quality was the notion without which, according to traditional morality, a woman could not marry. For women honor meant premarital virginity. A vivid example of hypertrophy of this perception of honor by naive native speakers provides one of the Russian folk tales:

- You are fools! - the old woman said. - You run carelessly and jump over the ditch! Don't you understand? Look, what have you done: you're a fool, have lost you honor! Who will marry you?

In this case, 'honor' is understood purely physically and is equal to hymen, and the loss of honor - to premarital defloration, regardless of whether it occurred as a result of immoral acts or from an accident.

With the development of female emancipation and the softening of moral standards, the specific understanding of female honor had to lose its meaning gradually, which was also reflected in the language. In both English, German and Russian explanatory dictionaries the meaning of the word 'honor' ('die Ehre'), as a female honor, is marked 'obsolete'. However, it should be noted that in German and Russian dictionaries this type of honor is given a more prominent place than in English dictionaries.

\section{Conclusion}

Let us summarize the main results of the research:

1. The concept 'honor' occupies an important place in the system of values contained in the naive picture of the world of the English, German and Russian languages and finds rich realization in units of different levels of these languages.

2. An indispensable component of the meaning of linguistic units associated with the concept 'honor' is the element of attitude, i.e. manifestation of this or that opinion about someone or something. In other words, the language units associated with the concept 'honour' necessarily carry an attitudinal meaning.

3. In English, German and Russian naive pictures of the world, the main subject of the evaluation action, being carried out with the help of the concept 'honor' is the society in which the speaker lives. However, in German and Russian the meaning of self-esteem of the individual is also assigned to honor, i.e. in German and Russian cultures the concept 'honor', in addition to social meaning, also has quite defined personal and moral sense.

4. In naive pictures of the world of the speakers of the English, German and Russian languages there are certain differences in the correlation of the cultural and linguistic concept 'honor' with specific areas of social activity. For a native English speaker, the concept 'honor' is associated with a large number of areas of practical, everyday activities (for example, study, gambling, financial transactions) rather than for a native German speaker.

\section{References}

1. D.S. Likhachev, News RAN, Series of literature and language 52 (1), 3-9 (1993)

2. I.V. Aleshchanova, N.A. Frolova, E.V. Morozova, M.R. Zheltukhina, Proceedings of the 7th International Scientific and Practical Conference Current Issues of Linguistics and Didactics: The Interdisciplinary Approach in Humanities (CILDIAH 2017), Advances in Social Science, Education and Humanities Research (ASSEHR) 97, 19-24 (2017)

3. E.V. Bobyreva, O.A. Dmitrieva, M.R. Zheltukhina, M.V. Busygina, Proceedings of the 7th International Scientific and Practical Conference Current Issues of Linguistics and Didactics: The Interdisciplinary Approach in Humanities (CILDIAH 2017). Advances in Social Science, Education and Humanities Research (ASSEHR) 97, 52-56 (2017)

4. D.Yu. Gulinov, M.R. Zheltukhina, L.A. Shestak, G.G. Slyshkin, V.V. Katermina, L.D. Chervyakova, Modern Journal of Language Teaching Methods 8 (2), 159-173 (2018)

5. G.G. Slyshkin, Concept of personality as an element of linguistic and cultural historical sphere (based on the concept of "Talleyrand"), Ethnohermeneutik und kognitive Linguistik, (Landau: Verlag Empirishe Pädagogik, 2007)

6. E.M. Safronofa, L.S. Beylinson, N.V. Zolotykh, T.U. Shevchenko, International Journal Of Environmental \& Science Education 11(16), 89688980 (2016)

7. Yu.S. Stepanov, 'Words', 'Concepts', 'Things'. To a new synthesis in the science of culture. Benvenist E. Dictionary of Indo-European social terms (Progress-Univers, Moscow, 1995)

8. E.S. Buneeva, Linguistic personality: cultural concepts, (1996)

9. D.S. Likhachev, News RAN, Series of literature and language 52 (1), 3-9 (1993)

10. N.D. Arutyunova, Science, 3-6 (1993)

11. V.I. Karasik, Linguistic personality: cultural concepts (1996)

12. A.A. Khudyakov, Linguistic personality: cultural concepts, 97-103 (1996)

13. Y.D. Apresyan, Selected papers, volume I. Lexical semantics (School "Languages of Russian culture", Moscow, 1995)

14. Y.D. Apresyan, Selected papers, vol. II. The integrated description and system lexicography (School "Languages of Russian culture", Moscow, 
1995)

15. J.L. Borges, Essays in three volumes, 1 (Riga, 1994)

16. V.I. Karasik, Cultural dominants in language, Linguistic personality: cultural concepts, 3-16 (1996)

17. A.S. Hornby, E.V. Gatenby, H. Wakefield, The Advanced Learner's Dictionary of Current English ('Sengilei', Stavropol, 1992)

18. Synonym-Wörterbuch. Sinnverwandte Ausdrücke der deutschen Sprache. (Leipzig, 1986)

19. A.S. Hornby, E.V. Gatenby, H. Wakefield, The Advanced Learner's Dictionary of Current English ('Sengilei', Stavropol, 1992)

20. A.S. Hornby, E.V. Gatenby, H. Wakefield, The Advanced Learner's Dictionary of Current English ('Sengilei', Stavropol, 1992)

21. Webster's New World Thesaurus (N.Y., 1975)

22. Webster's New American Dictionary (Books, Inc., Publishers, N.Y. and Washington, D.C., 1968)

23. N. Davis, O. Ergunova, V. Lizunkov, E. Malushko, European Proceedings of Social and Behavioural Sciences 26, 550-556 (2017)

24. E. Malushko, O. Maletina, V. Tsybaneva, Advances in Social Science Education and Humanities Research (ASSEHR) 97, 175-180 (2017) 